\title{
KAJIAN TEOLOGIS TENTANG PEREMPUAN DAN PERANANNYA DALAM PENDIDIKAN AGAMA KRISTEN GEREJA
}

\author{
Heliyanti Kalintabu \\ Sekolah Tinggi Teologi Anderson Manado \\ heliyanti.kalintabu@sttanderson.ac.id
}

\begin{abstract}
Abstrak
Peran perempuan pada masa kini bukanlah sesuatu yang tabu untuk diperbincangkan. Tulisan ini memuat kajian tentang perempuan, feminisme, kesamaan esensial laki-laki dan perempuan, pandangan teologis tentang perempuan, dan peranannya dalam pendidikan agama Kristen. Metode yang digunakan dalam penelitian ini adalah penelitian kualitatif. Yang bermaksud memahami suatu fenomena yang dialami oleh subjek penelitian misalnya perilaku, persepsi, motivasi, tindakan, dan lainlain, secara holistik di dalam gereja. Cara deskripsi dalam bentuk kata-kata dan bahasa, pada suatu konteks khusus yang alamiah dan dengan memanfaatkan berbagai metode alamiah. Hasil dari penelitian ini adalah perempuan yang memiliki latar belakang Pendidikan Agama Kristen dapat berperan di dalam gereja sebagai pendeta Pendidikan Agama Kristen, pengajar, diaken, anggota di dalam badan atau komisi Pendidikan Agama Kristen, dan guru Sekolah Minggu. Ilmu pengetahuan tentang Pendidikan Agama Kristen yang dimiliki oleh kaum perempuan adalah anugerah Allah, yang sudah seharusnya untuk dikembangkan dan dipraktikkan di dalam gereja.
\end{abstract}

Kata Kunci: Perempuan, Pendidikan Agama Kristen Gereja

\begin{abstract}
The role of women in the present is not something that is taboo to be discussed. This paper contains studies on women, feminism, the essential similarities of men and women, theological views about women, and their role in Christian Religious Education. The method used in this research is qualitative research which intends to understand a phenomenon experienced by research subjects such as behavior, perception, motivation, action, etc., holistically in the church how to describe in the form of words and language, in a special natural context and by utilizing various natural methods. The results of this study are women who have a background in Christian Religious Education can play a role in the church as pastors of Christian Religious Education, teachers, deacons, members in Christian Religious Education bodies or commissions, and Sunday school teachers. Knowledge about Christian Religious Education that is owned by women is a gift of God, which is supposed to be developed and practiced in the church.
\end{abstract}

Keywords: Women, Christian Religious Education in the Church. 


\section{Pendahuluan}

Peran perempuan pada masa sekarang bukanlah menjadi yang tabu untuk diperbincangkan. Sangat banyak perempuan yang telah berperan di dalam gereja, keluarga, organisasi pemerintahan, organisasi swasta, lembaga-lembaga pemerintahan. Namun, sangat disayangkan, dalam keterkaitannya dengan gereja, masih terdapat gerejagereja yang belum memperdayakan perempuan, dikarenakan masyarakat masih memiliki kebudayaan patriarki maskulin.

Di dalam gereja masa kini, terdapat beberapa pemahaman yang berbeda tentang peran perempuan, baik dalam pelayanan maupun memimpin dalam sebuah organisasi gerejawi. Dalam pernyataan Emanuel Gerrit Singgih di dalam Implikasi Gender dalam Lembaga Pendidikan Teologi yang dikutip oleh Elkana Chrisna Wijaya, mengatakan bahwa, kemajuan dan keterlibatan dari peranan perempuan belum terlalu signifikan dan belum menggembirakan. Minimnya tokoh teologi dan tenaga edukasi dalam kekristenan disebabkan oleh adanya anggapan bahwa kaum perempuan tidak pantas menempati posisi tersebut. Singgih menjelaskan bahwa budaya patriarki (maskulin) telah banyak memengaruhi dan mengkonstruksi pemikiran masyarakat bahwa laki-laki adalah sebagai pemegang kendali. ${ }^{1}$

Istilah "patriarki” secara harfiah
berarti
kekuasaan Mulanya kata ini digunakan untuk menyebut suatu jenis "keluarga yang dikuasai oleh kaum laki-laki", yaitu

\footnotetext{
${ }^{1}$ Elkana Chrisna Wijaya, "Perdebatan Peranan Wanita Dalam Organisasi Kristen: Tinjauan Terhadap Isu Kepemimpinan Kontemporer". Evangelikal: Jurnal Teologi Injili dan Pembinaan Warga Jemaat. Volume 1, Nomor 2, Juli 2017, 104. Diakses $30 \quad$ Mei 2020. http://journal.sttsimpson.ac.id/index.php/EJTI
}

rumah tangga besar patriark yang terdiri dari kaum perempuan, laki-laki muda, anak-anak, budak, dan pelayan rumah tangga yang semuanya berada di bawah kekuasaan laki-laki. Namun sekarang, istilah patriark digunakan lebih umum untuk menyebut kekuasaan laki-laki. Budaya partriarki menguasai dan mewarnai hidup laki-laki dan perempuan. Hampir di segala bidang dominasi dan kontrol laki-laki terhadap perempuan sangat terasa. Banyak orang beranggapan bahwa laki-laki dilahirkan untuk berkuasa dan perempuan untuk dikuasai. Mereka beranggapan bahwa patriarki selalu ada dan akan terus ada, dan bahwa seperti tatanan alam lainnya, patriarki tidak bisa diubah. Tetapi ada juga pendapat yang mengatakan bahwa patriarki bukan buatan alam, tetapi buatan manusia yang dapat diubah. $^{2}$

Jadi, masih terdapat perbedaan pemahaman tentang perempuan. Perbedaan pemahaman ini juga terjadi di dalam gereja dan organisasi. Perbedaan pemahaman ini terjadi karena latar belakang budaya yang memahami (memosisikan) laki-laki sebagai pemegang kendali.

Penulis secara pribadi melalui penulisan ini, mengamati bahwa kurangnya peran perempuan di dalam pelayanan gerejawi seperti halnya dalam Pendidikan Agama Kristen di Gereja. Namun demikian, tujuan utama dari penulisan ini adalah untuk memberikan kontribusi pemikiran, khususnya bagi para pihak yang berkepentingan.

\section{Metode}

Metode penelitian yang digunakan adalah penelitian kualitatif. Menurut Lexy

\footnotetext{
2 Asnath Yiwa Natar. Ketika Perempuan Berteologi: Berteologi Feminis Kontekstual (Yogyakarta: Taman Pustaka Kristen, 2012), 2526.
} 
Moleong, penelitian kualitatif adalah penelitian yang bermaksud untuk memahami suatu fenomena yang dialami oleh subjek penelitian misalnya perilaku, persepsi, motivasi, tindakan, dan kajian. Adapun cara mendeskripsi data dalam penelitian ini yaitu deskripsi dalam bentuk kata-kata dan bahasa, pada suatu konteks khusus yang alamiah dan dengan memanfaatkan berbagai metode ilmiah. ${ }^{3}$ Dalam penelitian ini, penulis menggunakan tinjauan dan studi literatur atas perempuan dalam perspektif Alkitab dan peran perempuan dalam Pendidikan Agama Kristen di dalam gereja.

\section{Pembahasan}

\section{A. Feminisme}

Feminisme adalah gerakan yang tersebar luas dan kompleks, yang mencakup segala sesuatu dari hasil yang setara untuk kegiatan yang sama. Feminisme adalah faham yang mengatakan bahwa bahwa perempuan harus memiliki hak yang sama dengan laki-laki dan harus diperlakukan dengan rasa hormat yang sama. Feminisme merupakan seruan untuk keadilan. Ketika orang Kristen melihat bahwa terdapat adanya ketidak adilan kesetaraan gender, orang Kristen tersebut menentangnya dan menjadi pendukung keadilan bagi perempuan. Kata "Feminisme" memfokuskan pada tujuan bersama dari gerakan feminis, gerakan feminis bermaksud bahwa perempuan dan lakilaki adalah sama-sama manusia, para perempuan harus dianggap sebagai manusia sama dengan laki-laki dalam semua dimensi kehidupan pribadi dan publik, sehingga harus dilakukan perubahan sosial untuk memastikan bahwa perempuan telah diperlakukan adil sama dengan laki-laki di dalam semua

${ }^{3}$ Lexy Moleong, Metodologi Penelitian Kualitatif (Bandung: Rosdakarya, 2012), 6. dimensi kehidupan pribadi dan publik. ${ }^{4}$

Terdapat dua mazhab (aliran) feminisme yang sangat penting dalam konteks ini untuk teologi dan gereja yaitu: (a) Feminisme Reformis; (b) Feminisme Revolusioner (atau radikal). Di satu sisi, Feminisme Reformis mengasumsikan bahwa Allah memang nyata bagi kita di dalam Kristus, dan bahwa gereja, terlepas dari kesalahannya, adalah agen penebusan Allah. Gereja membutuhkan pertobatan, reformasi, dan rekonstruksi sesuai dengan wawasan baru yang memungkinkan Injil untuk bersinar dengan lebih terang. ${ }^{5}$

Di lain sisi, Feminisme Revolusioner menolak prinsip kekristenan (Yudaisme dan Islam, dan mungkin Buddhisme, Taoisme, dan agama-agama lainnya), karena itu adalah konstruksi laki-laki, dan akibatnya terdapat definisi korup atas hal ini. Feminis revolusioner mengklaim bahwa perempuan hanya dapat menemukan identitas sejati mereka melalui penolakan terhadap semua agama patriarki dan pembangunan agama-agama feminis baru. ${ }^{6}$

\section{B. Kesamaan Esensial antara Laki- laki dan Perempuan dalam Penciptaan}

Dalam Kejadian 1:26-28, dapat dilihat bahwa, jika digabungkan keputusan Allah (Baiklah Kita menjadikan manusia...., supaya mereka berkuasa....) ciptaan Allah (maka Allah menciptakan) dan pemberkatan Allah

\footnotetext{
4 Bobby Kurnia Putrawan, "Perempuan dan Kepemimpinan Gereja: Suatu Dialog Perspektif Hermeneutika Feminis" Volume 6, No. 1, April 2020 (114-126). Diakses 30 Mei 2020. http://www.sttpb.ac.id/e-journal/index.php/kurios

5 Putrawan, "Perempuan dan Kepemimpinan Gereja: Suatu Dialog Perspektif Hermeneutika Feminis" 116.

6 Putrawan, "Perempuan dan Kepemimpinan Gereja: Suatu Dialog Perspektif Hermeneutika Feminis" 116.
} 
(Beranakcuculah ...; penuhilah bumi dan taklukkanlah itu ...), terdapat tiga kebenaran fundamental tentang manusia: Allah menciptakan mereka menurut gambar-Nya; Ia menciptakan mereka sebagai laki-laki dan perempuan seraya mengaruniai mereka tugas bahagia untuk berkembang biak; dan bahwa Ia memberi mereka kekuasaan atas bumi dan segala binatang yang ada di dalamnya. ${ }^{7}$

Jadi, sejak permulaan penciptaan manusia, Allah sudah menciptakan lakilaki dan perempuan. Laki-laki dan perempuan sama-sama menjadi ahli waris baik atas citra Ilahi maupun atas kekuasaan di bumi. Dalam teks Kejadian 1:27-28, tidak terdapat sesuatu yang menunjukkan bahwa salah satu dari jenis kelamin itu lebih besar keserupaannya dengan Allah daripada yang lain, atau lebih besar tanggung jawabnya atas bumi daripada yang lain, baik dalam ihwal keserupaan dengan Allah, maupun dalam ihwal tanggung jawab atas pengelolaan bumi. Laki-laki dan perempuan dari awalnya sama-sama mendapat bagian dan kepercayaan dari Allah, karena laki-laki dan perempuan adalah sama-sama diciptakan oleh Allah dan serupa dengan gambar-Nya.

Pernyataan tiga rangkap tentang penciptaan Allah dalam ayat 27 bukan semata-mata paralelisme puitis. Dalam ayat tersebut jelas terdapat penitikberatan yang disengaja. Ditegaskan sebanyak dua kali bahwa Allah menciptakan manusia menurut gambar-Nya, dan ketiga kalinya menunjuk kepada gambar Ilahi itu diganti dengan kata laki-laki dan perempuan. Namun, jika kedua jenis seks itu adalah sesuai dengan gambar Allah, maka di dalamnya ada inklusif bukan saja

7 John Stott, Isu-isu Global Menantang Kepemimpinan Kristiani Penilaian Atas Masalah Sosial dan Moral Kontemporer (Jakarta: Yayasan Komunikasi Bina Kasih, 1996), 338. kesejatian kemanusiaan (kemanusiaan otentik yang mencerminkan ke Ilahian), melainkan juga pluralitas (ikatan cinta manusia yang mencerminkan ikatan yang dipersatukan ketiga pribadi Trinitas itu). ${ }^{8}$ Oleh sebab itu, Dewan Gereja-Gereja Kristus di Amerika Serikat menerbitkan sebuah buku ibadah yaitu An Inclusive Language Lectionary, di mana dalam buku tersebut telah dihapus kosa kata yang berbau gender. ${ }^{9}$ Jadi, dari ayat tersebut jelas memberikan pemahaman bahwa Allah menciptakan laki-laki dan perempuan menurut gambar-Nya, dan memberikan tugas dan tanggung jawab yang sama kepada mereka, dalam hal ini Allah tidak melihat ciptaan-Nya mempunyai hak yang berbeda satu dengan yang lain, tetapi sama-sama memiliki hak waris, tidak ada yang superior maupun inferior.

Kesepadanan gender yang asali ini menjadi rusak oleh kejatuhan manusia ke dalam dosa. Sebagian dari hukuman yang dijatuhkan Allah atas ketidaktaatan Adam dan Hawa ialah firman-Nya kepada perempuan: "Engkau akan berahi kepada suamimu dan ia akan berkuasa atasmu". Jadi, kedua jenis kelamin itu akan mengalami alienasi antara satu dengan yang lain. Dengan demikian akan berlaku kenyataan bahwa yang satu akan menguasai yang lain. Sifat saling isi mengisi dari semula ini dimaksudkan bahwa ketentuan laki-laki akan "mengepalai" seperti yang diutarakan Paulus, tetapi akibat kejatuhan manusia ke dalam dosa, 'pengepalaan' laki-laki ini merosot menjadi "penguasaan". ${ }^{10}$ Karena kenyataan inilah, hukuman Allah kepada perempuan dimanfaatkan habis-habisan oleh kaum laki-laki, dan dengan brutal mereka menindas dan mengungkung kaum perempuan dengan cara-cara yang

\footnotetext{
${ }^{8}$ Stott, Isu-isu Global, 339.

${ }^{9}$ Stott, Isu-isu Global, 339.

${ }^{10}$ Stott, Isu-isu Global, 341.
} 
melenceng dari maksud Allah. Seperti yang terjadi dalam kebudayaankebudayaan yang memandang salah tentang perempuan, dalam otobiografinya Mahatma Gandhi "An Autobiography or The Story of my Experiment with Truth" mengatakan bahwa seorang suami Hindu menganggap dirinya tuan dan majikan istrinya, yang sepanjang waktu harus berjaga-jaga di sampingnya untuk melayani setiap kebutuhannya. Bahkan ada juga suku-suku yang memasang kaum perempuan di depan bajak sebagai pengganti kerbau atau sapi. Contohcontoh ini merupakan pengeksploitasian yang tidak sah dan tidak baik. ${ }^{11}$

Dalam Perjanjian Lama, suami selain sebagai seorang bapak bagi anggota keluarganya, ia juga adalah baal (tuan atau penguasa atas mereka). Tetapi walaupun seperti itu, kaum Perempuan tidak dipandang rendah atau diperlakukan tidak baik. Misalnya, di dalam Ulangan $31: 12$, mereka dianggap bagian yang integral dari umat perjanjian itu sehingga laki-laki, perempuan, dan anak-anak berkumpul untuk bersama-sama mendengar pembacaan Taurat dan mengambil bagian dalam ibadah dan kebolehan-kebolehan istri yang baik diberikan pujian, seperti yang tertulis di dalam Amsal 31:30. ${ }^{12}$

\section{Pandangan Teologis tentang Perempuan}

Dalam lingkungan orang Yahudi, Yudaisme secara terbuka diskriminatif terhadap perempuan. Perempuan dianggap tidak mampu memberikan kesaksian bahkan perempuan tidak layak berpartisipasi dalam sebagian besar perayaan keagamaan. ${ }^{13}$ Di masa Yesus,

\footnotetext{
${ }^{11}$ Stott, Isu-isu Global, 345.

${ }^{12}$ Stott, Isu-isu Global, 345.

${ }^{13}$ Kasomo Daniel, "The Role Of Women In The Church In Africa" International Journal of Sociology and Anthropology Vol.2 No.6 June
}

perempuan adalah orang-orang yang tidak dikenal, tidak penting, yang tidak masuk hitungan, yang kehidupan dan eksistensinya bergantung pada figur lakilaki: bergantung kepada ayah ketika seorang perempuan tersebut masih muda, bergantung kepada suami ketika sudah menikah, dan bergantung pada anak lakilaki ketika perempuan tersebut sudah tua. Namun, seperti yang diperlihatkan oleh Yesus, perempuan adalah orang yang disalahpahami, yang iman dan kesetiaannya telah terbukti layak atas pengakuan dan kekaguman serta perempuan-perempuan tersebut samasama dipanggil untuk melakukan pekerjaan domestik seumur hidup. ${ }^{14}$

Perempuan Kanaan yang berani memohon pertolongan dari seseorang yang berasal dari komunitas agama lain. Sebagai seorang perempuan Kanaan, ia berada di luar komunitas agama yang dominan. Dari aspek lokasi kelahiran dan geografis, ia adalah perempuan SiroFenisia; berdasarkan agama dan etnis, ia adalah seorang Kanaan. Dalam klasifikasi yang dibuat orang Yahudi, perempuan itu adalah seorang Kafir (Gentile) atau bukan orang Yahudi, "seorang penyembah berhala, orang yang asing terhadap kebudayaan mereka dan berada di luar perjanjian (Allah mereka)". Bagi orang Yahudi, perempuan tersebut adalah "orang luar", di luar lingkaran kasih penyelamatan Allah. Bagi murid-murid Yesus, perempuan tersebut adalah orang luar yang seharusnya diusir dari antara mereka. Tetapi, orang bukan Yahudi yang tidak dikenal dan penyembah berhala ini berani melanggar aturan-aturan sosial, menginterupsi istirahat Yesus dan mengganggu para murid. Terus-menerus

2010, 126-139. Accessed 13 Februari 2020. http://www.academicjournals.org/ijsa.

14 Hope S. Antone, Pendidikan Kristiani Kontekstual (Jakarta: BPK Gunung Mulia,2010), 73. 
mendesakkan permohonannya untuk ditolong. ${ }^{15}$ Di saat murid-murid Yesus menanggapi perempuan tersebut dengan sinis, tetapi tanggapan Yesus berbeda dengan murid-murid-Nya, Yesus mengabulkan permintaan perempuan tersebut dengan menyembuhkan anaknya yang sedang sakit. Hal ini menunjukkan bahwa Yesus mengasihi perempuan tersebut dan tidak menjauh karena aturanaturan sosial orang Yahudi.

Sewaktu perjalanan keliling Yesus dari kota ke kota, di samping para murid yang semuanya adalah laki-laki, Yesus juga ditemani oleh sekelompok perempuan yang telah disembuhkan-Nya dan melayani Dia dari kekayaan mereka ( Luk. 8:1 dyb). Selanjutnya, Yesus berbicara di sumur Yakub dengan seorang perempuan Samaria dan berdosa, sekaligus memiliki tiga kekurangan. Tetapi pada kenyataannya, Yesus terlibat diskusi dengan perempuan tersebut (Yoh. 4:7 dyb). Selain itu dalam Yohanes 8:1 dyb., seorang perempuan yang kedapatan berzinah dan kemudian dihadapkan kepada Dia. Yesus bersikap lembut pada perempuan tersebut dan menolak untuk menghukumnya. Peristiwa yang hampir sama adalah ketika seorang pelacur mendatangi Yesus dari belakang sewaktu hendak duduk makan, membasahi kakiNya dengan air matanya, menyekanya dengan rambutnya dan mencium kakiNya. Yesus menyambut kasih yang ditunjukkan perempuan itu, sebagai pernyataan syukur atas pengampunannya. Karena Alkitab berkata: "Aku datang bukan untuk mencari orang benar melainkan orang berdosa." 16 Peristiwa ini menunjukkan bahwa sikap Yesus terhadap Perempuan sangatlah berbeda dengan sikap dan pandangan orang-orang yang mengganggap rendah perempuan.

\footnotetext{
15 Antone, Pendidikan Kristiani Kontekstual, 8182.

${ }^{16}$ Stott, Isu-isu Global, 344.
}

Sikap Yesus yang seperti ini mengembalikan kepada kaum perempuan takaran martabat yang hilang akibat kejatuhan manusia ke dalam dosa. Yesus menunjukkan kasih-Nya kepada kaum perempuan, tanpa membenci atau menghakimi.

Yesus menyambut perempuan berdosa di hadapan khalayak ramai, padahal seorang laki-laki Yahudi dilarang berbicara kepada perempuan di tengah jalan, baik itu istri, putri, atau saudaranya perempuan. Tidak hanya itu, dalam mengajarkan hukum Taurat kepada kaum perempuan adalah sesuatu yang haram; "lebih baik kata-kata yang ada di dalam hukum Taurat itu dibakar". Demikianlah menurut Talmud, daripada mempercayakannya kepada perempuan. Tetapi, Yesus melanggar aturan tradisi dan adat kebiasaan ini. Ketika Maria dari Betania duduk dekat kaki Yesus dan terus mendengar ajaran-Nya, Yesus memuji dia karena melakukan hal satu-satunya yang menjadi saksi pertama kebangkitan-Nya (Luk. 10:38; Yoh. 20:10). Yesus mengembalikan kutukan kejatuhan, mengembalikan kepada perempuan keagungannya yang lengkap, dan memproklamasikan bagi umat-Nya berkat kesepadanan gender sebagaimana yang telah dikaruniakan Allah kepada manusia pada awal mulanya. ${ }^{17}$

Paul Jewett dalam John Stott dalam Man as Male and Female mengajukkan sebuah dalil kemitraan (partnership) yang semula diperuntukan Allah bagi pasangan laki-laki dan perempuan diganti pada zaman Perjanjian Lama dengan model hirarkis, yang diserap dari lingkungan kebudayaan Israel. Namun, dengan kedatangan Yesus, terjadi sesuatu yang baru. Yesus berbicara tentang perempuan dan menunjuk kepada perempuan selaku manusia seutuhnya dan

\footnotetext{
${ }^{17}$ Stott, Isu-isu Global, 345.
} 
sepadan dengan laki-laki. Yesus sungguh-sungguh adalah sosok revolusioner. ${ }^{18}$

Paulus juga menangkap makna kesepadanan, di dalam Galatia 3:28 "Dalam hal ini tidak ada orang Yahudi atau orang Yunani, tidak ada hamba atau orang merdeka, tidak ada Laki-laki atau Perempuan, karena kamu semua adalah satu di dalam Kristus Yesus." Artinya bahwa, sehubungan dengan derajat manusia di hadapan Allah, baik laki-laki dan perempuan dapat menikmati relasi yang sama dengan Dia, oleh sebab itu, perbedaan rasial, nasional, sosial, kultur dan gender menjadi tidak relevan lagi. Manusia dari semua ras dan kelas, dan dari kedua jenis kelamin adalah sepadan di hadapan Dia. Konteksnya adalah konteks pembenaran hanya oleh anugerah dan hanya melalui iman. Dengan tegas dinyatakan bahwa semua orang yang oleh iman berada di dalam Kristus Yesus, adalah sama-sama diterima untuk menjadi anak-anak Allah, tanpa pengecualian, pendiskriminasian atau favoritisme berdasarkan ras, jenis kelamin, atau kelas. ${ }^{19}$ Di hadapan Allah dan di dalam Kristus Yesus tidak ada laki-laki atau perempuan, tidak ada inferior dan superior, semua memiliki derajat yang sama, baik laki-laki dan perempuan memiliki kesempatan yang sama untuk menikmati anugerah Allah yaitu karya keselamatan yang telah Yesus Kristus kerjakan di atas kayu salib untuk menebus dosa manusia.

Jadi, kesederajatan gender yang telah dirusak oleh kejatuhan manusia ke dalam dosa, ditegakkan kembali oleh Yesus Kristus sendiri. Kejatuhan manusia diperoleh kembali oleh karya keselamatan yang telah Yesus kerjakan, dan keutuhan ciptaan antara laki-laki dan perempuan

\footnotetext{
${ }^{18}$ Stott, Isu-isu Global, 348.

${ }^{19}$ Stott, Isu-isu Global, 345.
}

ditegakkan kembali oleh Yesus Kristus. Maka dengan demikian dalam segi nilai laki-laki dan perempuan mutlak sederajat di hadapan Allah. Sama-sama diciptakan menurut gambar dan rupa Allah, samasama dibenarkan oleh anugerah melalui iman, sama-sama mengalami regenerasi oleh Roh Kudus, sama-sama pewaris anugerah Allah yang ada dalam Kristus Yesus, seperti yang tertulis dalam 1 Petrus 3:7 bahwa para suami untuk hidup bijaksana dengan istrinya, sebagai kaum yang lebih lemah, dan menghormati mereka sebagai teman pewaris dari kasih karunia, yaitu kehidupan. Laki-laki dan perempuan sederajat tetapi mereka bukanlah serupa. Kesederajatan dan keserupaan adalah dua hal yang sangat berbeda.

Tidak ada satupun pernyataan di dalam Alkitab yang menyarankan agar kaum perempuan sebaiknya jangan memburu karir atau mencari nafkahnya sendiri; atau bahwa perempuan yang sudah menikah harus melakukan semua kegiatan berbelanja, memasak dan membersihkan, sementara suaminya tinggal menikmati hasil jerih payah sang istri dengan berpangku tangan. Peribahasa Jerman yang membatasi wilayah kekuasaan perempuan dengan istilah Kinder, Kuche, Kirche (anak, dapur, gereja). Lantas apa kata Alkitab tentang peran masing-masing gender berserta semua hubungannya? Dalam Kejadian 2:18-22 menjelaskan bahwa tidak baik kalau manusia itu seorang diri saja, oleh sebab itu, Tuhan Allah menjadikan seorang penolong bagi manusia itu yaitu seorang perempuan yang sepadan dengan dia. $^{20}$

Dua kutipan di atas menjelaskan bahwa, meskipun Allah menciptakan laki-laki dan perempuan sederajat, Allah juga menciptakan mereka saling berbeda.

\footnotetext{
${ }^{20}$ Stott, Isu-isu Global, 346.
} 
Sebab dalam Kejadian 1, maskulinitas dan feminitas dikaitkan dengan gambar Allah, sedang dalam Kejadian 2 laki-laki dan perempuan dikaitkan satu sama lain, Hawa sebagai yang diambil dari Adam dan dibawa kepadanya. Malah, Kejadian 1 menyatakan kesederajatan kedua jenis gender tersebut; Kejadian 2 menjelaskan bahwa sepadan bukan berarti serupa melainkan saling mengisi, komplementer. ${ }^{21}$ Karena laki-laki dan perempuan adalah sepadan (berdasarkan ciptaan dan di dalam Kristus), maka tidak mungkin terdapat inferioritas yang satu ketimbang yang lain, tetapi karena lakilaki dan perempuan adalah komplementer, maka tidak mungkin terdapat keserupaan yang satu dengan yang lain. Kebenaran ganda tersebut mempertajam penglihatan terhadap hubungan laki-laki dan perempuan serta peranannya masing-masing. Karena lakilaki dan perempuan adalah yang diciptakan Allah dengan martabat yang sepadan, maka laki-laki dan perempuan harus saling menghormati, mengasihi, melayani, dan bukan saling membenci. Karena laki-laki dan perempuan diciptakan secara komplementer, saling melengkapi, maka laki-laki dan perempuan harus mengakui perbedaan mereka dan jangan berusaha meniadakannya atau saling merebut ciri khas masing-masing. Sehubungan dengan keistimewaan penciptaan Hawa, Matthew Henry dalam John Stott, menulis dengan kalimat-kalimat yang penuh ke dalaman bahwa perempuan bukan diciptakan dari kepala laki-laki supaya mengepalai dia, bukan juga dari kaki seorang laki-laki supaya diinjak-injak oleh dia, melainkan dari sisi laki-laki supaya berdampingan dengan dia, di bawah lengan laki-laki supaya terlindung, dan dekat dengan jantung laki-laki supaya perempuan

${ }^{21}$ Stott, Isu-isu Global, 347. dikasihi. $^{22}$

\section{Peranan Perempuan dalam Pendidikan Agama Kristen Gereja}

Pendidikan merupakan terjemahan dari bahasa Inggris yaitu "education". Kata "education" berasal dari bahasa latin: ducere yang berarti membimbing (to lead) ditambah awalan "e" yang berarti keluar (out). Jadi arti dasar dari pendidikan adalah suatu tindakan untuk membimbing keluar. ${ }^{23}$

Adapun hubungan pendidikan dengan Pendidikan Agama Kristen adalah suatu usaha tindakan untuk membimbing ajaran-ajaran Kristen. Pendidikan Agama Kristen juga merupakan pendidikan yang khusus yaitu dalam dimensi religius manusia. Hal ini berarti usaha pendidikan tersebut dikhususkan pada bagaimana pencarian akan yang transenden serta pemberian ekspresi dari seseorang terhadap yang transenden tadi dikembangkan, serta dimungkinkan tetap terjadi pada manusia masa kini. Pendidikan Agama Kristen menunjuk kepada persekutuan iman yang melakukan tugas pendidikan agamawi, yaitu persekutuan iman Kristen. Pendidikan Agama Kristen sebagai usaha pendidikan yang mempunyai hakikat politis. Artinya bahwa dalam Pendidikan Agama Kristen tidak hanya ada intervensi dalam kehidupan individual seseorang di bidang kerohaniannya saja, tetapi juga memengaruhi cara dan sikap mereka ketika menjalani kehidupan dalam konteks masyarakatnya. Pendidikan apapun apalagi Pendidikan Agama Kristen, tidak pernah hanya mempunyai konsekuensi pribadi. Demikian pula spiritualitas Kristen tidak dapat bersifat pribadi saja. Karena kekristenan dan

\footnotetext{
${ }^{22}$ Stott, Isu-isu Global, 348.

${ }^{23}$ Daniel Nuhamara, Pembimbing PAK (Bandung: Jurnal Info Media, 2009), 8.
} 
spiritualitas Kristen pada dasarnya mengalir dari hakikat panggilan Kristen yaitu untuk mengasihi Allah dengan cara atau melalui kasih kepada sesama. ${ }^{24}$

Pendidikan Agama Kristen menunjuk pada suatu maksud yaitu tugas gereja sebagai persekutuan iman untuk mendidik serta membina warganya maupun pihak lain sebagai tugas pelayanannya. ${ }^{25}$ Secara sosiologis, gereja adalah suatu persekutuan sosial yang mempunyai ciri khas yang membedakannya dengan persekutuan sosial lainnya. Secara teologis, definisi gereja adalah sebagai persekutuan orang percaya, yang mempersekutukan adalah kepercayaannya atau imannya kepada Allah yang menyatakan diri dalam Yesus Kristus. Hal ini disebut dengan iman Kristen. Secara sederhana iman Kristen dapat diartikan sebagai respons manusia terhadap Allah yang menyatakan diri dan kehendak-Nya itu mencapai puncaknya dalam diri Tuhan Yesus Kristus. ${ }^{26}$

Dalam kaitannya dengan peran perempuan, bukanlah sesuatu yang diragukan jika kaum perempuan dipanggil Allah untuk mengambil bagian dalam pelayanan gerejawi khususnya Pendidikan Agama Kristen gereja. Gereja Katolik dan Gereja Ortodoks Timur tidak memiliki Imam perempuan. Kedua gereja ini dengan tegas menentang perkembangan yang di dalamnya di mana kaum perempuan diberikan ruang di dalam pelayanan gereja. Tetapi berbeda dengan gereja Lutheran, misalnya gereja Lutheran di Skandinavia memiliki Imam perempuan. Gereja reformasi Perancis mulai menyetujui pentahbisan pendeta perempuan pada tahun 1965 dan Gereja Skotlandia pada tahun 1966. Di antara Gereja Inggris yang termasuk dalam 'British Free Churces' adalah Gereja

\footnotetext{
${ }^{24}$ Nuhamara, Pembimbing PAK, 26.

${ }^{25}$ Nuhamara, Pembimbing PAK, 5.

${ }^{26}$ Nuhamara, Pembimbing PAK, 7.
}

kongregasional yang sudah mempunyai pendeta perempuan pada tahun 1917, sedangkan gereja Metodis dan gereja Baptis menyusul dalam tahun-tahun berikutnya. $^{27}$

Di kalangan gereja Anglikan, peran perempuan dalam gereja tidak merata. Bishop R. O Hall dari Hongkong adalah yang pertama mengukuhkan seorang perempuan sebagai Imam pada tahun 1944. Dalam Konferensi Lambeth (Konferensi Uskup-Uskup Gereja Anglikan) tahun 1968 mengeluarkan pernyataan bahwa argumentasi teologis akan menyetujui atau menentang pentahbisan perempuan menjadi Imam (Pendeta) adalah seimbang. Namun, pada tahun 1975 Sinode Am Gereja Inggris menyatakan pendapatnya bahwa tidak ada keberatan fundamental terhadap pentahbisan perempuan sebagai Imam dalam Gereja Inggris. Kemudian pada konferensi Lambeth pada tahun 1978, para Uskup menerima fakta, bahwa di beberapa Provinsi, Gereja Anglikan telah mengukuhkan perempuan sebagai Imam dan menyutujui untuk menghormati hak masing-masing. ${ }^{28}$

Dalam kalangan Kristen tertentu, dalam kepatuhan yang menggebu-gebu dengan apa yang dikatakan Alkitab, serta merta akan mengatakan bahwa perempuan tidak boleh ditahbiskan sebagai Pendeta. Alasannya, bukan saja karena semua Rasul dan Penatua dalam zaman Perjanjian Baru adalah laki-laki, melainkan lebih-lebih karena dalam Alkitab telah menuliskan bahwa "perempuan harus berdiam diri dalam pertemuan-pertemuan jemaat" dan tidak diijinkan "mengajar atau memerintah laki-laki" (1Kor. 14:34; 1Tim. 2:12). ${ }^{29}$ Adapun konteks perintah Paulus kepada perempuan untuk berdiam diri seperti

\footnotetext{
${ }^{27}$ Stott, Isu-isu Global, 364.

${ }^{28}$ Stott, Isu-isu Global, 359.

${ }^{29}$ Stott, Isu-isu Global, 364.
} 
yang terdapat dalam Korintus yaitu terdapat beberapa perempuan Kristen pada saat itu sangat antusias dengan iman baru mereka sehingga menyela pembicara untuk bertanya, yang juga merupakan kebiasaan umum di sana pada waktu itu. Demi, menghindari kekacauan tersebut, Paulus menasehati mereka agar "bertanya kepada suami mereka di rumah" seperti yang dinyatakan di dalam 1 Korintus 14:35. Dalam suratnya kepada orangorang di Korintus, Paulus tidak hanya menasihati para perempuan tetapi juga orang-orang yang memiliki karunia bernubuat dan berbicara dalam bahasa lain agar mereka "berdiam diri" ketika rekan seiman sedang berbicara.

Perintah Paulus agar perempuan berdiam diri, tidak mengajar dan memerintah laki-laki, tidak hanya dituliskan kepada jemaat di Korintus, tetapi juga dituliskan kepada jemaat Efesus tepatnya dalam 1 Timotius 2:12. Adapun alasan bagi Paulus untuk mengatakan bahwa perempuanperempuan di Efesus harus berdiam diri untuk menerima ajaran, karena perempuan di Efesus memiliki pekerjaan yang tidak benar dari kacamata kebenaran Firman Tuhan. Dalam konteks ini, Paulus tidak hanya mendasarkan pernyataannya pada posisi yang ditunjukkan kepada perempuan, tetapi bahwa sebenarnya Paulus lebih menekankan prinsip penuntun dalam penerapannya yang universal dan kekal (1Kor. 11:2-16). Akibatnya, manusia jatuh ke dalam dosa, yang kemudian memperkuat kebenaran umum bahwa lebih mudah perempuan diperdaya daripada laki-laki. Karena itu tidaklah wajar perempuan merebut wewenang dalam menentukan baik asas maupun pelaksanaan persekutuan Kristen. ${ }^{30}$ Dari sisi geografis dan politis

30 Julens Makanata, "Sikap Perempuan dalam Ibadah Berdasarkan 1 Timotius" Evangelikal: Jurnal Teologi Injili dan Pembinaan Warga
Efesus adalah kota terpenting di provinsi Romawi wilayah Asia, terletak di wilayah pantai barat Turki modern yang merupakan tempat strategis dan pusat perdagangan, politik dan agama. Letak kota itu di muara sungai Kayster di antara pegunungan Koresos dan laut. Kota itu sekarang sudah tidak ditempati lagi, tetapi sedang digali dan barangkali merupakan reruntuhan dari Asia Kecil yang luas dan mengesankan. Wilayah terbesar kota itu dengan gedung teaternya, tempat permandian, perpustakaan, padar, dan jalan-jalan yang diperkeras dengan batu pualam. Tempat ini dikeramatkan sebagai tempat ibadah kepada berhala kesuburan Anatolia, Artemis atau Diana. dewi Artemis adalah dewi bulan orang Yunani yang sering digambarkan sebagai darah pemburu, sedangkan dewi Diana disebut dewi orang Yunani atau orang Italia Kuno yang sering disebut sebagai darah pemburu dalam bidang kehutanan dan kelahiran anak-anak. Dewi Diana digambarkan sebagai dewi yang memiliki banyak buah dada yang dianggap sebagai dewi kesuburan oleh orang-orang Efesus dari zaman Romawi diperlihatkan dada bergambar ilah-ilah Diana yang diabadikan di kuilnya. ${ }^{31}$ Setelah kuil Diana terbakar pada tahun $365 \mathrm{SM}$, perkembangan agama Kristen yang menolak sinkritisme terus menerus menghadapi perlawanan dari pihak para pemimpin agama yang sudah mapan pada saat itu. oleh sebab itu, hal inilah yang menjadi latar belakang mengapa banyak ilmu gaib dan ajaran-ajaran palsu berkembang di sana. Karena latar belakang inilah yang membuat orangorang pada saat itu memiliki pemahaman ajaran-ajaran palsu tidak terkecuali para

Jemaat Vol.2 No.1 (Januari 2018): 10-19. Diakses 13 Mei 2020. file:///C:/Users/User/Downloads/87250-3-PB.pdf.

31 Makanata, "Sikap Perempuan dalam Ibadah Berdasarkan 1 Timotius", 13. 
perempuan pada saat itu. ${ }^{32}$

T.M. Braunch dalam bukunya "Ucapan-ucapan Paulus yang Sulit" yang dikutip oleh Julens Makanata mengatakan bahwa nasihat Paulus dalam 1 Timotius 2:11 ditujukan kepada perempuanperempuan di Efesus untuk berdiam diri karena mereka adalah pendukung ajaran sesat yang telah menerima doktrin-doktrin yang bertentangan dengan kebenaran iman Kristen. Situasi ini menimbulkan gejolak tersendiri dalam jemaat di Efesus. Ajaran-ajaran yang salah mulai mengacaukan situasi kehidupan jemaat dan rumah tangga Paulus yang telah tertata rapi. Karena alasan itulah, Paulus melarang perempuan-perempuan di Efesus untuk berdiam diri dan menerima ajaran dengan patuh. Perempuan dituntut untuk patuh, taat serta berdiam diri untuk menerima ajaran. Ketaatan yang diperintahkan kepada mereka adalah kemungkinan besar ketaatan kepada para tua-tua dalam jemaat yang merupakan penjaga kebenaran dan ibadah yang teratur. Doktrin yang diterima oleh perempuan-perempuan di Efesus adalah doktrin-doktrin yang tidak lagi berpusat pada firman Tuhan, melainkan doktrin yang menyeleweng dari firman Tuhan (Alkitab). ${ }^{33}$

Melihat kembali tentang perintah ganda kepada perempuan untuk berdiam diri dalam pertemuan jemaat. Pertanyaannya adalah bagaimana caranya memahami kondisi tersebut? John Stott mengemukan pendapatnya yang merujuk kepada pernyataan Paulus (1Tim. 2:11). Di dalam teks ini, Paulus mengemukakan dua antithesis. Pertama, antara menerima ajaran atau berdiam diri dan mengajar. Kedua, antara patuh dan menguasai. Pokok yang substantif adalah kepala dari

32 Makanata, "Sikap Perempuan dalam Ibadah Berdasarkan 1 Timotius" 14.

33 Makanata, "Sikap Perempuan dalam Ibadah Berdasarkan 1 Timotius" 14. perempuan adalah laki-laki, yang dasarnya terdapat dalam kisah penciptaan manusia (karena Adam yang pertama dijadikan, kemudian barulah Hawa). Tetapi perintah tentang keharusan perempuan berdiam diri dan larangan perempuan mengajar, walaupun kontroversial pada kenyataan bahwa yang 'tergoda' adalah Hawa dan bukan Adam, lebih cenderuang pada sebuah ekspresi dari sindrom menguasai-patuh, dan bukan suatu tambahan. Dalam perbedaan gender yang nyata antara laki-laki dan perempuan, terlihat tidak ada sesuatu yang inheren, menjadi tidak layak, jika perempuan mengajar laki-laki. Jadi, walaupun keabsahan kepatuhan perempuan kepada laki-laki adalah permanen dan universal, sebab laki-laki memang sudah diciptakan Allah. ${ }^{34}$

Menyikapi persoalan di atas, Stott memberi beberapa jawaban yaitu sebagai berikut: ada tiga syarat yang perlu diperhatikan seorang perempuan ketika ia terpanggil menjadi pengajar Pendidikan Agama Kristen (PAK) Gereja. ${ }^{35}$

Pertama, isi pengajarannya. Yesus memilih, mengangkat, dan mengilhami para rasul-Nya menjadi pengajar yang jitu dari gereja-Nya, yang kebenaran ajarannya tidak mungkin diragukan dan semua mereka adalah laki-laki, mungkin karena sifat pelayanan mereka adalah memberi dasar bagi kepercayaan umat, dan karena itu memerlukan otoritas yang cukup besar. Tetapi kini keadaannya sama sekali berbeda. Alkitab sudah lama rampung dan tidak ada lagi Rasul di dalam gereja. Sebagai gantinya maka fungsi para pengajar Kristen adalah untuk memelihara doktrin Rasuli dalam Perjanjian Baru. ${ }^{36}$

Kedua, konteks pelayanan Firman atau pengajaran itulah yang harus menjadi

\footnotetext{
${ }^{34}$ Stott, Isu-isu Global, 365.

${ }^{35}$ Stott, Isu-isu Global, 365.

${ }^{36}$ Stott, Isu-isu Global, 366.
} 
suatu tim pelayanan gerejawi. Baik langsung maupun tidak langsung, Paulus selalu merujuk pada tua-tua (jamak) dalam setiap gereja. Patut disyukuri bahwa banyak gereja masa kini yang sudah meninggalkan kepemimpinan tunggal, dan berbalik ke cara Perjanjian Baru dengan pola bimbingan pastoralnya yang dikelola secara tim dan bukan secara perseorangan. Makna yang terdapat di balik kebijaksanaan ini ialah bahwa berbagai karunia yang disatupadukan adalah lebih besar kuasanya daripada kemampuan satu orang. Dalam tim seperti itu tentu harus tersedia tempat bagi perempuan. Tetapi, agar sejalan dengan ajaran Alkitab mengenai kepemimpinan maskulin, maka tim itu wajar untuk diketuai oleh seorang lakilaki. ${ }^{37}$ Transposisi (perubahan) kultural tujuannya adalah memberi pembungkus kultural yang baru dan serasi kepada intisari penyataan yang tidak kunjung berubah. Pada abad I kepemimpinan maskulin dilukiskan dengan ekstrem yakni diharuskannya perempuan memakai tudung kepala dan dengan larangan mengajar pada laki-laki; apakah kepemimpinan maskulin kini tidak mungkin diungkapkan melalui suatu cara yang di satu pihak setia pada ajaran Alkitab, tetapi di lain pihak relevan bagi abad ke-20, dengan mengikutsertakan perempuan dalam tim pelayanan gerejawi yang diketuai oleh laki-laki? konsep pelayanan secara tim ini juga akan menyelesaikan masalah siasat (disiplin) gerejawi. Siasat menyangkut otoritas, dan karena itu mustahil dapat diserahkan pada seorang perempuan. Itu benar, tetapi siasat juga tidak mungkin diserahkan pada seorang laki-laki sendiri. ${ }^{38}$

Ketiga, yang diperlukan bila seorang perempuan terpanggil menjadi

\footnotetext{
${ }^{37}$ Stott, Isu-isu Global, 365.

${ }^{38}$ Stott, Isu-isu Global, 365.
}

pelayan Firman, adalah gaya. Para pengajar Kristen bukanlah pembual, entah itu laki-laki maupun perempuan. Kerendahan hati para Guru Kristen harus terlihat, baik dalam ketundukan mereka pada otoritas Alkitab maupun dalam kesederhanaan pribadi yang memancar dari pelayanan mereka. Yesus berkali-kali mengeritik menyinggung perilaku otoriter Farisi yang gila hormat, atau penguasapenguasa duniawi yang gila kekuasaan (Mat. 23:1; Mar. 10:42). Petrus yang peka terhadap cobaan yang dihadapi semua pemimpin Kristiani yang menjadi angkuh dan menganggap dirinya hebat, menasihati teman-teman penatua agar selalu menunjukkan sikap pengabdian diri, dan jangan sekali-kali berbuat seolah-olah mau memerintah atas mereka yang dipercayakan kepadanya, melainkan, hendaklah menjadi teladan bagi kawanan domba Kristus (1Ptr. 5:1). Nasihat yang ditujukan kepada para lakilaki inilah justru ditemukan kemajuannya pada perempuan, yang telah berdamai dengan identitas femininnya dan karena itu sekali-kali tidak berusaha lagi atau merasa tidak perlu lagi berusaha untuk menjadi atau berperilaku sama seperti laki-laki. ${ }^{39}$

Dalam konteks penegasan ini, penulis sependapat bahwa perempuan dapat diberikan kesempatan dalam suatu pelayanan gerejawi khususnya berperan dalam Pendidikan Agama Kristen (PAK) Gereja. Asalkan isi ajarannya yang Alkitabiah, konteksnya adalah pelayanan secara tim (artinya bahwa kegiatan mengajar itu dilakukan oleh perempuan sebagai anggota dari suatu tim yang dikepalai oleh seorang laki-laki), dan gayanya bukan gaya ingin menguasai, melainkan gaya pengabdian diri. Sebab, dengan keadaan yang seperti itu mereka akan mendayagunakan karunia-karunia

\footnotetext{
${ }^{39}$ Stott, Isu-isu Global, 366.
} 
yang ada pada mereka tanpa berpretensi menjalankan "kepemimpinan" yang bukan milik mereka. Jika ketiga ketentuan ini terpenuhi, maka apa yang dilakukannya adalah tidak lebih daripada memanfaatkan karunia mengajar yang didapatnya dari Tuhan, tanpa pretensi mau mengepalai laki-laki. Allah memakai laki-laki dan perempuan yang terpanggil dalam rencana-Nya termasuk juga tugas pelayanan dalam suatu gereja.

Dalam konteks yang sama dapat dikatakan bahwa Allah memanggil umatNya, umat-Nya dalam hal ini adalah Lakilaki dan perempuan untuk memberitakan Firman-Nya. Allah memakai pelayanan manusia yang seakan-akan bekerja sebagai wakil-Nya. Ini bukan berarti Allah menyerahkan kepada manusia hak dan kehormatan-Nya, tetapi bahwa melalui bibir manusia, Allah melaksanakan karya-Nya. Sebagaimana seperti seorang tukang memakai alat untuk melaksanakan pekerjaannya.

Walaupun terdapat beberapa gereja yang belum memberi posisi sebagai gembala kepada perempuan, namun bukan berarti bahwa panggilan melayani tidak dapat dilakukan oleh kaum perempuan. Kaum perempuan yang memiliki latar belakang teologi dan Pendidikan Agama Kristen dapat diberdayakan oleh gereja setempat dan menyalurkan karunia panggilannya dalam fungsi-fungsi pelayanan sebagai berikut:

- Pendeta Pendidikan Agama Kristen. Pendeta PAK (Minister of Education) atau direktur PAK (Director of Christian Education) atau pembantu PAK (Assistant in Christian Education) adalah pejabat atau pelayan khusus gereja yang diangkat untuk mengelola pendidikan seluruh jemaat dengan bekerja sama dengan Badan atau Komisi PAK. Seorang tenaga professional yang terlatih dengan pengetahuan khusus di bidang pendidikan gereja. Pendeta PAK adalah tenaga spesialis, administrator, supervisor yang mengurus, mengawasi dan memperbaiki pendidikan menyeluruh dari jemaat. Bekerjasama dengan pendeta atau Badan PAK dalam fungsinya melayani segi-segi pedagogis dari program PAK jemaat staf professional gereja. $^{40}$

- Pengajar (Doktor). Tentang jabatan seorang "Doktor" dinyatakan bahwa tugasnya adalah pendidikan teologi dan katekisasi. Menitikberatkan perhatian akan peranan teologi yang harus diembannya. ${ }^{41}$

- Diaken. Dalam perjanjian baru juga menyebutkan peranan seorang perempuan yang bernama Febe. "Ia adalah seorang diaken di jemaat di Kengkrea. Paulus berkata bahwa Febe telah memberikan bantuan kepada banyak orang juga kepadaku sendiri" (Roma 16:1-2). Febe membuktikan bahwa hatinya tertuju kepada Allah dan pekerjaan-Nya. Ia cakap, bermartabat dan dapat dipercaya untuk melaksanakan tanggung jawab yang besar. Febe telah menjadi rekan kerja yang baik bagi Paulus dan jemaat di Roma. ${ }^{42}$

- Personalia Badan atau Komisi PAK. Anggota-anggota dari badan atau komisi PAK ini terdiri dari: majelis jemaat, pejabat-pejabat pendidikan, wakil-wakil dari Sekolah Minggu, Pendeta PAK. Komisi atau badan ini

40 Eli Tanya, Gereja dan Pendidikan Agama Kristen: Mencermati Peranan Pedagogis Gereja (Cipanas: STT Cipanas, 2006), 86-87.

${ }^{41}$ Tanya, Gereja dan Pendidikan Agama Kristen: Mencermati Peranan Pedagogis Gereja, 137.

${ }^{42}$ Shintia Maria Kapojos, Randy Frank Rouw, Hengki Wijaya. "Implikasi Kehidupan Perempuan Yahudi Bagi Gereja Masa Kini”. Evangelikal: Jurnal Teologi Injili dan Pembinaan Warga Jemaat Volume 3, Nomor 2, Juli 2019: 136-143. Diakses 30 Mei 2020. 
bukan hanya bertanggung jawab kepada Sekolah Minggu saja, melainkan kepada program menyeluruh dari segenap jemaat. Mengatur dan mengkoordinasi pendidikan dalam jemaat, misalnya Sekolah Minggu, Sekolah Liburan (VBS), Kelas-kelas Alkitab, kelompok-kelompok studi khusus, kelompok perempuan dan kelompok laki-laki. Selain itu badan atau komisi PAK ini juga dapat menentukan pemilihan pejabat-pejabat pendidikan dan guru-guru. Melakukan supervisor dan pelatihan bagi staf dan guru-guru. Penyediaan kepustakaan dan sumbersumber pendidikan, melakukan kerjasama dengan para orangtua, pencarian beasiswa untuk kegiatan liburan (kamp dan retret), PAK di sekolah atau kerjasama oikumenis dengan gereja-gereja lain. ${ }^{43}$

- Guru Sekolah Minggu. Kaum perempuan yang memiliki latar belakang PAK juga dapat difungsikan sebagai guru sekolah minggu maupun ketua komisi pelayanan anak.

Di Indonesia, peran perempuan sebagai pengajar PAK Gereja belum merata. Seperti halnya di gereja Katolik, gereja Reformed dan gereja Injili Fundamentalis belum memberi kesempatan bagi perempuan untuk dapat ditahbiskan menjadi seorang Pendeta, tetapi bukan berarti gereja-gereja tersebut benar-benar tertutup dengan keberadaan perempuan, kenyataannya bahwa beberapa perempuan telah dilibatkan di dalam pelayanan. Seperti pelayanan doa, musik, guru Sekolah Minggu. Tetapi ada sebagian besar gereja selain dari gerejagereja yang disebutkan sebelumnya, telah memberikan kesempatan untuk seorang perempuan menjadi Pendeta tertahbis,

\footnotetext{
${ }^{43}$ Tanya, Gereja dan Pendidikan Agama Kristen: Mencermati Peranan Pedagogis Gereja, 82-83.
}

seorang diaken, majelis, dan lain-lain. Perbedaan ini disebabkan oleh pemahaman teologi yang berbeda-beda, persepsi yang berbeda, sehingga melahirkan suatu sudut pandang yang berbeda tentang peran perempuan dalam Pendidikan Agama Kristen gereja. Peranan perempuan dalam Pendidikan Agama Kristen gereja adalah sebuah pemberian Allah yang harus dikembangkan demi untuk kemuliaan Allah, untuk kemajuan gereja, karena Pendidikan Agama Kristen yang dimiliki oleh seorang perempuan adalah dari Dia, oleh Dia dan untuk Dia.

\section{Kesimpulan}

Perempuan yang memiliki latar belakang Pendidikan Agama Kristen harus dapat diperhatikan dan dikembangkan oleh gereja. Oleh karena itu, tidak salah jika perempuan diberikan kesempatan dalam suatu pelayanan gerejawi dalam hal ini adalah Pendidikan Agama Kristen gereja. Asalkan isi ajarannya alkitabiah, konteksnya adalah pelayanan secara tim (artinya bahwa kegiatan mengajar itu dilakukan oleh perempuan sebagai anggota dari suatu tim yang dikepalai oleh seorang laki-laki), dan gayanya bukan gaya ingin menguasai, melainkan gaya pengabdian diri. Perempuan adalah seorang yang istimewa di hadapan Allah. Perempuan juga merupakan ciptaan Allah yang mempunyai karunia memberitakan Firman. Perempuan yang memiliki latar belakang Pendidikan Agama Kristen dapat berperan di dalam gereja sebagai pendeta Pendidikan Agama Kristen, pengajar, diaken, anggota di dalam badan atau komisi PAK, guru Sekolah Minggu. Ilmu pengetahuan tentang Pendidikan Agama Kristen yang dimiliki oleh kaum perempuan adalah anugerah Allah, yang sudah seharusnya untuk dikembangkan dan dipraktekkan di dalam gereja bagi 
kemuliaan Allah.

\section{Referensi}

Antone S. Hope. Pendidikan Kristiani Kontekstual, Jakarta: BPK Gunung Mulia, 2010.

Daniel, Kasomo "The Role Of Women In The Church In Africa" International Journal of Sociology and Anthropology Vol.2, No.6 (Juni 2010), 126-139. Accessed pada tanggal $11 \quad$ Mei 2020. http://www.academicjournals.org/ijs a.

Kapojos, Maria, Shintia., Randy Frank

Rouw., dan Wijaya, Hengki. "Implikasi Kehidupan Perempuan Yahudi Bagi Gereja Masa Kini”. Evangelikal: Jurnal Teologi Injili dan Pembinaan Warga Jemaat Volume 3, Nomor 2, Juli 2019: 136143. Diakses 30 Mei 2020.

Makanata, Julens. "Sikap Perempuan dalam Ibadah Berdasarkan 1 Timotius" Evangelikal: Jurnal Teologi Injili dan Pembinaan Warga Jemaat Vol.2, No.1 (Januari 2018): 10-19. Diakses 13 Mei 2020. file:///C:/Users/User/Downloads/87250-3-PB.pdf.

Moleong, Lexy. Metodologi Penelitian Kualitatif. Bandung: Rosdakarya, 2012.

Natar, Yiwa, Asnath. Ketika Perempuan Berteologi: Berteologi Feminis Kontekstual, Yogyakarta: Taman Pustaka Kristen, 2012.

Nuhamara, Daniel. Pembimbing PAK. Bandung: Jurnal Info Media, 2009.

Putrawan, Kurnia, Bobby. "Perempuan dan Kepemimpinan Gereja: Suatu Dialog Perspektif Hermeneutika Feminis" Volume 6, No. 1, (April 2020): 114-126. Diakses 30 Mei 2020. http://www.sttpb.ac.id/e- journal/index.php/kurios.

Stott, John. Isu-isu Global Menantang Kepemimpinan Kristiani Penilaian Atas Masalah Sosial dan Moral Kontemporer. Jakarta: Yayasan Komunikasi Bina Kasih, 1996.

Tanya, Eli. Gereja dan Pendidikan Agama Kristen: Mencermati Peranan Pedagogis Gereja.Cipanas: STT Cipanas, 2006.

Wijaya, Chrisna, Elkana. "Perdebatan Peranan Wanita dalam Organisasi Kristen: Tinjauan Terhadap Isu Kepemimpinan Kontemporer". Evangelikal: Jurnal Teologi Injili dan Pembinaan Warga Jemaat. Volume 1, No. 2 (Juli 2017), 104. Diakses $\quad 30 \quad$ Mei 2020. http://journal.sttsimpson.ac.id/index. $\mathrm{php} / \mathrm{EJTI}$ 
Jurnal Shanan

ISSN: 2549-8061

Volume 4 Nomor 1 Maret 2020 hal. 57-72 